Shamruk N. B.

Ph.D. in Law, Associate Professor of the Department of Administrative, Civil and Commercial Law and Process, Academy of the State Penitentiary Service, Chernihiv, Ukraine

\title{
AUTHORITIES OF THE PROSECUTOR'S OFFICE AS AN EFFICIENT SUBJECT IN THE FIELD OF PREVENTING AND COUNTERACTING DOMESTIC VIOLENCE IN UKRAINE
}

The article is dedicated to the clarification of the meaning, place and role of the prosecutor's office in order to work effectively together with state and non-state institutions in the field of prevention and counteraction to domestic violence in Ukrainian families in present.

Article 6 of the Law of Ukraine "On Prevention and Counteraction to Domestic Violence" contains a rather spectacular list of subjects authorized to carry out measures in the field of prevention and counteraction to domestic violence. In this list, which has as many as 19 subjects, law-enforcement authorities are also included, the role of which is difficult to overestimate, especially when it comes to counteracting this shameful phenomenon. After all, to date in Ukraine, the work on domestic violence combating is complex and includes a set of measures that carry social and economic, pedagogical, psycho-correctional and law-enforcement nature, and therefore it is very important, because it is the law-enforcement authorities (in this case, these are authorized subdivisions of the bodies of the National Police of Ukraine, courts, prosecutor's office and authorized probation bodies), are empowered through their own competence to apply coercive measures to the persons, who have already committed such violence.

Key words: prosecutor's office, law-enforcement authorities, subjects, measures of counteraction, prevention, domestic violence, prophylactic measures, victim of violence.

Target setting. Protection from violent actions is one of the basic human rights in a modern civilized society. However, unfortunately, despite the level of development of the state institution, which is the first and must provide such protection to its citizens, domestic violence is one of the most widespread crimes committed almost every day. Taking into account Slavic mentality, where all family affairs are closed and, a priori, are not subjected to publicity, most victims perceive family violence as a matter of routine, as an inevitable aspect of family life and do not report it. One category of victims who have the courage to seek help from state authorities often returns with nothing 
back because they do not perceive them and do not fully understand the versatility and complexity of the situation, while others are depressed in the possibility of obtaining real protection and restoring justice due to the weakness of domestic legal and political base.

That is why the activities of law-enforcement authorities, including the prosecutor's office, can become the impulse that will form zero tolerance to violence, and thus clearly illustrates the right of every person to a decent attitude and protection from the state.

Actual scientific researches and issues analysis. Known academic lawyers, such as: O. V. Boiko, A. O. Halai, H. O. Horbova, F. K. Dumko, O. D. Kolomoiets, V. S. Krasii, K. B. Levchenko, Yu. V. Lysiuk, O. M. Melnyk, I. B. Trokhym, N. B. Shamruk and others have investigated the problematic issues of the work of the prosecutor's office authorities in the area of counteracting and preventing domestic violence in Ukrainian families.

Purpose setting. The purpose of the article is to ascertain the value, the place and role of the prosecutor's office authorities in order to work effectively together with both governmental and nongovernmental institutions in preventing and counteracting domestic violence in Ukrainian families in the realities of today.

Statement of basic materials. The end of 2017 was sign for Ukraine for the real implementation of the principles of Council of Europe Convention on preventing and combating violence against women and domestic violence and fighting against these shameful phenomena (also known as the Istanbul Convention), since the Verkhovna Rada of Ukraine finally adopted a "European" and "modern" Law of Ukraine "On Prevention and Counteraction to Domestic Violence" that reflected the realities of the present and adopted the Law of Ukraine "On Amendments to the Criminal and Criminal Procedural Codes of Ukraine in order to implement the principles of Council of Europe Convention on preventing and counteracting violence against women and domestic violence and fighting against these phenomena".

So, the Article 6 of the Law of Ukraine "On Prevention and Counteraction to Domestic Violence" already contains a rather spectacular list of subjects authorized to carry out measures in the field of prevention and counteraction to domestic violence. In this list, which has as many as 19 subjects, law-enforcement authorities are also in- 
cluded, the role of which is difficult to overestimate, especially when it comes to counteracting this shameful phenomenon. After all, to date in Ukraine, the work on domestic violence combating is complex and includes a set of measures that carry social and economic, pedagogical, psycho-correctional and law-enforcement nature, and therefore it is very important, because it is the law-enforcement authorities (in this case, these are authorized subdivisions of the agencies of the National Police of Ukraine, courts, prosecutor's office and authorized probation bodies), are empowered through their own competence to apply coercive measures to the persons, who have already committed such violence.

One should agree with opinion of O.D. Kolomoiets that it is possible to evaluate the activity of law-enforcement authorities and other subjects of counteracting and preventing domestic violence in different ways, but one should agree that state's activity in the field of our investigation does not correspond to the realities of the present because it does not provide an integrated protection of the rights and freedoms of the victims of domestic violence in accordance with international rules and norms of domestic legislation. In particular, this concerns the provision of a normal mechanism for abolishing violence immediately after the victim's request. One of the real steps in solving this problem may be implementing of measures to increase the level of interaction and coordination of all state bodies and establishing close cooperation between law-enforcement authorities, in particular with non-governmental organizations [5, p.72].

So, it is worth agreeing that the activities of the units of the National Police are key to preventing and counteracting domestic violence, since it is precisely this state institution that is required to directly implement a set of preventive (prophylactic) and cessation measures in this area. Among other things, it should be noted that the direct indication that measures are being carried out by officers of the service, by district police officers or by the employees of Children's Affairs Division somewhat reduces the range of subjects (from the units of the internal affairs bodies) who can take part in the conduct of activities in this area. The situation when an operational group, which, as it is known consists of the employees of different units of law-enforcement authorities, comes on call about committing a crime, 
and during such operation, the fact of domestic violence is also noted, may be an example. Accordingly, having revealed such circumstances, the mentioned subjects must react appropriately. Another example is when victims of domestic violence address to patrol staff, and the officers must respond and take appropriate measures. Thus, there are cases when the subject line-up becomes slightly broader than the normative and legal acts provide, although in general, in this situation, it can't be spoken about the lack of normative and legal provision for such interaction and activity.

The Law of Ukraine "On Prevention and Counteraction to Domestic Violence" states that the authorities of the Prosecutor's Office [1] are also among the other bodies and institutions entrusted with the functions of implementing measures in the field of preventing and counteracting domestic violence.

The prosecutors' activity in counteracting domestic violence in our opinion have the following main directions:

- supervision of observing legislation that ensures normal development of family relations;

- direct revealing violence and taking necessary measures, as well as representing the interests of victims of domestic violence in the courts for the purpose of protection or restoration of persons' violated rights.

Prosecutor's supervision in this area includes a complex of deeds and prosecutor's legal acts arising from his powers and with the help of which he solves the tasks he faces: to detect, to eliminate, to prevent the violation of the laws of Ukraine "On Prevention and Counteraction to Domestic Violence", "On The Protection of Childhood" and other laws, to bring the perpetrators to legal liability.

It should be noted that there is currently no departmental regulation of the implementation of the prosecutor's supervision of compliance with legislation on counteracting domestic violence in the complex. There are separate orders that regulate the implementation of prosecutor's supervision in this area. For example, the Order No 16gn dated 06.12.2014 "On organizing activities of the authorities of the prosecutor's office for the protection of children's rights and freedoms" [3].

The existence of guidance on the need to prevent violence against children is an indisputable plus of the system of normative and legal provision for counteracting domestic violence. It should be noted that 
the specified legal act contains several instructions on the interaction, in particular, it states that when organizing and conducting supervisory inspections, prosecutors have to:

- actively cooperate on these issues with public organizations that carry out activity in the field of child protection;

- protect children's rights through the provision of a fundamental legal assessment of the activities of the relevant bodies of state authority and control, law enforcement agencies;

- study the state of execution by penal authorities, local selfgovernment bodies and internal affairs agencies of their duties in relation to preventing offenses and crimes among children and adolescents, to coordinate this activity;

- protect social, residential, property and personal non-property children's rights using representative powers. If there are grounds to take measures to ensure claims. To initiate review of illegal court decisions in time.

- hear information from the heads of the relevant bodies and services, heads of penal bodies and local self-government bodies on the implementation of laws requirements on the protection of children's rights and freedoms, including in the area of preventing offenses among children at the coordination and interagency meetings;

- ensure supervision on observing children's rights and freedoms by the bodies conducting operational search activity.

If necessary, the experts should be involved and the issue concerning participation of the representatives of Commissioner of the Verkhovna Rada of Ukraine for Human Rights, of Commissioner of the President of Ukraine for Children's Rights, of public and human rights organizations to use actively the possibilities of the media in order to cover the activity of the authorities of the prosecutor's office in protecting children's rights should be decided. Prevent public disclosure of information that may indicate the identity of a child who committed the offense or who was the victim of a crime [3].

This order may in fact be the basis for the development of other normative and legal acts regarding the conduct of the prosecutor's office of supervisory activities in the field of counteracting domestic violence. 
In our opinion, the main tasks of the prosecutor's oversight of the observance of legislation on domestic violence preventing should be:

- supervision over compliance with laws aimed at combating domestic violence by all the subjects defined in the Law of Ukraine "On Prevention and Counteraction to Domestic Violence";

- identification and prosecution of persons guilty of violating the law;

- establishment and elimination of causes and conditions that contribute to violation of the said legislation;

- renewal of violated rights of victims of domestic violence, further protecting them from violence.

In order to achieve the above mentioned tasks, the Law of Ukraine "On Prosecutor's Office" gave the following powers to prosecutors:

- to enter the premises of state authorities and local selfgovernment bodies, associations of citizens, enterprises, institutions and organizations regardless of the forms of ownership, subordination or affiliation, to military units, institutions without special permits, where these are implemented unhindered by a certificate confirming the occupied position; to have access to the documents and materials required for the inspection, including on written request, and those containing commercial secret or confidential information. To request in writing a submission to the Prosecutor's Office in order to verify these documents and materials, issuing necessary certificates, including those relating to transactions and accounts of legal entities and other organizations, in order to resolve issues related to verification;

- to demand the verification of decisions, prescriptions, instructions, orders and other acts and documents, to receive information on the state of legality and measures for its getting;

- to require the heads and collegial bodies to carry out inspections, audits of activities of subordinated and controlled enterprises, institutions, organizations and other structures, regardless of ownership, as well as the allocation of specialists for conducting inspections, departmental and non-departmental expert assessments;

- to call officials and citizens, to demand from them oral or written explanations concerning violations of law $[2 ; 7$, p. 40].

The objects of prosecutorial inspections should become bodies and institutions that are responsible for the implementation of 
measures for preventing domestic violence, and in some cases, the family members.

Thus, in order to increase the potential of the prosecutor's office in the field of counteracting domestic violence, it would be appropriate to develop and implement in practice the Order of the General Prosecutor's Office "On the Peculiarities of the Human Rights Protection of the Authorities of the Prosecutor's Office in the Sphere of Counteracting Domestic Violence".

Particular attention should be paid to the of the issues concerning prosecutor's participating in the judicial process concerning the representation of victims of domestic violence, as well as certain categories of citizens who suffer from it, in particular minors. So, according to the data of the Office of the Prosecutor General of Ukraine on using representative powers in order to protect the rights of minors in 2016, according to the results of the prosecutor's investigations, the rights of more than 200 children were renewed, more than 468 submissions and applications were made, 269 unlawful acts were appealed, and 50 servicemen were brought to justice that eloquently testifies prosecutors' use of civil and legal measures of responding on violations of law revealed in this area [7].

The main tasks of the representation of a prosecutor in court, according to the order "On organizing prosecutors' activities regarding the representation of state interests in court and while executing court decisions" should be considered a real protection of the rights and legitimate interests of persons who are not able to protect their rights independently for any reason or exercise procedural powers, an uncertain range of persons whose rights are violated at the same time, as well as protection of the interests of the state that are violated or may be violated as a result of unlawful acts of individuals or corporations.

Prosecutors carry out their representative functions by: preparing and appealing to the court with claims, applications, administrative lawsuits; participation in court trials; initiating review of illegal court decisions; protecting citizen's rights or state's interests while executing court decisions; applying measures envisaged by the law in order to eliminate violations of law in the course of conducting legal proceedings, liability of those responsible for these persons. 
Conclusions. Taking into account the foregoing, we can state that prosecutor's response to the violations revealed during supervising the observance and application of the laws on preventing domestic violence has its own peculiarities which must be taken into account when forming a new regulatory framework. To do this, a separate order (in addition to the already existing order of the General Prosecutor's Office of Ukraine) requires the establishment of principles on the activities of a prosecutor for protecting victims of domestic violence, which would determine the clear competence and the procedure for responding to the facts of domestic violence.

\section{References}

1. Information from the Verkhovna Rada (2018), On Prevention and Counteraction to Domestic Violence: Law of Ukraine, dated December 7, 2017, No 2229-VIII, No 5.

2. Information from the Verkhovna Rada (2015), On the Prosecutor's Office: Law of Ukraine, dated October 14, 2014, No 1697-VII, No 2-3.

3. Ukraine (2014), On Organizing Activities of the Authorities of the Prosecutor's Office for thePprotection of Children's Rights and Freedoms: Order, the General Prosecutor's Office of Ukraine, available at: URL: http://zakon.rada.gov.ua/rada/show/v0016900-14 (accessed 10 January 2019).

4. Ukraine (2018), On Organizing Prosecutors' Activity Regarding the Representation of the State Interests in Court and While Executing Court Decisions: Order, the General Prosecutor's Office of Ukraine, available at: http://zakon.rada.gov.ua/rada/show/v0186900-18 (accessed 08 January 2019).

5. Kolomoiets, O. D. (2010), Administrative and legal regulation of responsibility for committing domestic violence, failure to comply with a protective provision or with a correctional programme. Ph.D. in Law Thesis, Zaporizhzhia.

6. Shamruk, N. B. (2012), Administrative and legal principles of interaction of the subjects of counteracting domestic violence. Ph.D. in Law Thesis, Kyiv.

7. Kocheymyrovska, O. O., Podilchak, O. M., Sevruk, O. R. and Khrystova, H. O. (2010), Prosecutor's supervision over compliance with the laws of Ukraine on preventing violence against children, Scientific and practical guide, “K.I.S.”, Kyiv. 


\section{Шамрук Н. Б. ОРГАНИ ПРОКУРАТУРИ ЯК ДІЕВИЙ СУБ'СКТ У СФЕРІ ЗАПОБІГАННЯ ТА ПРОТИДІЇ ДОМАШНЬОМУ НАСИЛЬСТВУ В УКРАЇНІ}

Статтю присвячено з'ясуванню значення, місия та ролі органів прокуратури для ефективної роботи сумісно як з державними, так $і$ недержавними інституціями у сфері запобігання та протидії домашньому насильству в українскких родинах в умовах сьогодення.

Стаття 6 Закону Украӥни «Про запобігання та протидію домашньому насильству» містить доволі вражаючий перелік суб'єктів, щуо наділені правом здійснювати заходи у сфері запобігання та протидії домашньому насильству. У чей перелік, який налічує аж 19 суб'єктів, включено і правоохоронні органи, роль яких важко переочінити, особливо, коли мова йде про питання протидї цьому ганебному явищу. Адже на сьогодні в Украӥні діяльність з протидії домашньому насильству носить комплексний характер $і$ включає в себе сукупність заходів, щуо мають сочіально-економічний, педагогічний, психокорекційний та правоохоронний характер, а тому має досить важливе значення, бо саме правоохоронні органи (в намому випадку, ие повноважені підрозділи органів Національної поліиії України, суди, прокуратура та уповноважені органи з питань пробаціï) через власну компетенцію наділені можливістю застосовувати заходи примусу до осіб, які вже вчинили вияви такого насильства.

Ключові слова: органи прокуратури, правоохоронні органи, суб'єкти, заходи протидї, запобігання, домашнє насильство, профілактика, жертва насильства. 